\title{
JUURNAL.RU
}

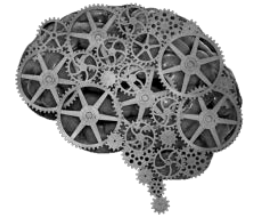

COMPANY GROUP "INTELLEKT"

Котанджян В.А. Саратовский нащиональный исследовательский государственный университет имени

Н.Г. Чернышевского

Саратов, Россия

doi: 10.18411/lj2016-9-2-06

idsp 000001: lj2016-18-2-06

\section{Анализ эффективности и перспективы борьбы с коррупцией в современной России}

В современных социально-экономических, а также политических условиях одной из ключевых проблем для органов власти Российской Федерации, требующей грамотного и эффективного решения, является коррупция.

В большинстве государств понятие коррупции раскрывается через составы отдельных правонарушений. Всего в законодательстве большинства стран мира можно отметить тенденцию к расширению понятия коррупции, которое выходит за пределы взяточничества и охватывает такие коррупционные проявления, как непотизм (кумовство), патронаж, многочисленные формы незаконного присвоения публичных средств.

Для отечественной правовой системы понятие «коррупция» относительно новое и не вполне определенное. Однако вряд ли отсутствие нормативного закрепления понятия «коррупции» создает препятствия в правоприменительной деятельности. Наличие нормативного определения коррупции вовсе не необходимо для квалификации деяний как коррупционных. Важно определение состава коррупционных правонарушений.

Считаем, что, коррупция многоаспектное, социально-экономическое, политическое и моральное явление, состоящее из целого комплекса противоправных действий и неэтичных поступков, а значит, довольно сложно дать единое, исчерпывающее определение этого понятия, которое бы отличало коррупционные явления от таких, которые не являются таковыми во всех случаях. 
Проблема коррупции в Российской Федерации получила широчайшее распространение среди всех ветвей власти и во всех слоях общества, а по степени коррумпированности наша страна занимает одно из лидирующих мест в мире. Коррупция - это интернациональная проблема, не имеющая границ и свойственная всем странам, независимо от их политического устройства и уровня экономического развития. Явление коррупции универсально для любого государственно-организованного общества, отличаются лишь масштаб и формы его проявления.

Рассматривая различные российские данные, можно заметить, что проведенная реформа образования, в частности введение ЕГЭ, привела к радикальному снижению уровня коррупции в системе высшего образования [1]. Но это не показатель. Нашелся всего лишь новый источник обогащения. Ведь коррупция в системе образования все равно не прекратила своего существования, скорее она просто сменила свое «амплуа» - раньше покупали бюджетные места в высших учебных заведениях, теперь же покупают результаты ЕГЭ.

Согласно докладу Общественной палаты, главной причиной коррупции можно считать отсутствие реального контроля гражданского общества над работой органов. Коррупция стала принимать системный характер, тем самым разрушая экономику и право. Среди самых проблемных областей стоит выделить - ЖКХ, устройство детей в детсады и школы, медицинская помощь [2]. Начинает нарастать чувство социальной несправедливости, особенно среди молодежи, но и сообщать в правоохранительные органы об этом граждане не спешат - бояться. На сегодняшний день лишь $22 \%$ опрошенных готовы сделать это. С другой стороны, можно понять и простой «рабочий класс» (преподаватели, врачи и др.). Сейчас заработные платы настолько малы, что практически невозможно прожить на эти деньги, поэтому порой «рабочий класс» просто вынужден прибегать к подобному, дабы хоть как-то существовать и обеспечивать семью. Пока особых успехов в борьбе с коррупцией нет, несмотря даже на принятые законодательные меры.

Стоит заметить, что за последние только три года в России было заведено около 17 тысяч уголовных дел на чиновников, уличенных в коррупции - от 
губернаторов и мэров до начальников ЖЭКов. Сумма средней взятки возросла десятки раз. И каждую неделю все новые материалы передаются в суды.

По мнению опрошенных «НГ» экспертов, борьба с коррупцией в России постепенно сходит на нет. И стоит согласиться с мнением вице-президента Центра политических технологий Алексея Макаркина, который считает, что власть, начиная борьбу с коррупцией, хочет лишь одернуть чиновников. Вторая задача власти - перехватить инициативу у оппозиции. Но если вести системную борьбу, как это было в Италии в 80-е годы, когда народ просто вышел на улицы, - на это сил вряд ли нам хватит. Власть не хочет, чтобы процесс принял неуправляемый характер [3].

Сейчас кого-то из чиновников возможно и осудят, но будут ли реальные сроки - неизвестно. Власть сегодня старается всеми своими действиями показать, насколько она сильна и не идет на уступки оппозиции. Стоит обратить внимание, что пока не было предпринято заметных шагов в борьбе с коррупцией. Причина - это игра на публику и попытка вырвать антикоррупционный «флаг» у оппозиционных партий.

К сожалению, на государственном уровне борьба с коррупцией представлена у нас в основном в виде планов и стратегий, а не реальных действий. Стоит отметить, что многое также зависит и от общества в целом.

Граждане должны собрать все силы, постараться создавать общественные движения и устраивать митинги, чтобы как-то повлиять на государство. Государству, в свою очередь, необходимо продолжать принимать меры по борьбе с коррупцией: редактировать законы и правоохранительные акты, ужесточать наказания, развивать гражданское общество (чтобы перед законом были равны все, в не зависимости от занимаемого поста), а также увеличить заработные платы в государственных учреждениях, чтобы граждане могли прожить на зарплату и у них не появлялось мысли о необходимости брать взятки.

При выработке современных стратегий борьбы с коррупционными преступлениями необходимо делать акцент на усиление институтов государственной власти, на повышение правосознания рядовых граждан, на активизацию деятельности общественных организаций. Необходимо провести реорганизацию правоохранительных органов, которая бы позволила улучшить 
эффективность их работы. Следует обратить особое внимание на создание системы социального правового контроля, предполагающего организацию жизни и деятельности, как конкретных чиновников, так и государственных структур на основе демократических законов. 


\section{Литература:}

1. Коррупция в России. Раздел «Современная Россия» URL: http://ru.wikipedia.org/wiki/Коррупция_в_России.

2. Ромашкин Т.В. Реформирование сферы ЖКХ в инновационных условиях. // Экономика и право. Новый университет. Серия «Экономика и право». № 5 (63). 2016. C. 39-41.

3. Газета «Независимая» 18.12.2012 г. URL: http://www.ng.ru/economics/201212-18/1_korrupcia.html. 